\title{
Inducing Spin Crossover in Amphiphilic Iron(III) Complexes
}

\author{
Paulo N. Martinho, ${ }^{[a]}$ Charles J. Harding, ${ }^{[b]}$ Helge Müller-Bunz,,${ }^{\text {[a] }}$ Martin Albrecht, ${ }^{[c]}$ and \\ Grace G. Morgan*[a]
}

Keywords: Amphiphiles / Spin crossover / Iron / Molecular switching / Magnetic properties

Thermal spin crossover (SCO) was induced in a high-spin Fe ${ }^{\text {III }}$ complex by alkylation of the polyamino ligand backbone. The SCO profile was responsive to chain length with partial crossover observed with $\mathrm{C}_{6}$ alkylation and full transi- tion upon lengthening to $\mathrm{C}_{12}$. No crossover was observed when the backbone was unfunctionalised, and all three complexes were obtained as unsolvated tetrafluoroborate salts.

\section{Introduction}

The ability of certain first-row transition-metal ions to switch the electronic state with thermal or optical stimulus has long been cited as having excellent potential for data storage ${ }^{[1]}$ and in recent years the emphasis has moved from synthesis of new examples towards suitable engineering of existing complexes into polymeric, ${ }^{[2]}$ amphiphilic ${ }^{[3 \mathrm{a}-3 \mathrm{e}]}$ or nanocrystalline ${ }^{[3 \mathrm{f}, 3 \mathrm{~g}]}$ environments. Most of the published examples focus on iron(II) ${ }^{[4]}$ but iron(III) ${ }^{[5]}$ is also a promising candidate and has the advantage of improved redox stability. ${ }^{[6]}$
$\left[\mathrm{Fe}(\mathrm{sal})_{2} \text { trien }\right]^{+}$has emerged in recent years as a prototypical $\mathrm{Fe}^{\mathrm{III}}$ spin crossover (SCO) ion ${ }^{[7]}$ and its ease of synthesis renders it an attractive candidate for further functionalisation for surface deposition or solution processing. The solid-state ion, however, shows a complex and unpredictable range of magnetic responses to thermal perturbation depending on the contents of the unit cell. ${ }^{[8-11]}$ A comprehensive report by Halcrow compared magnetic and structural data of new and known examples of solvated and unsolvated salts of $\left[\mathrm{Fe}(\mathrm{sal})_{2} \text { trien] }\right]^{+}$, and examined aspects of the crystal packing that might explain the variety of thermal responses. ${ }^{[12]}$ In particular the influence of the change
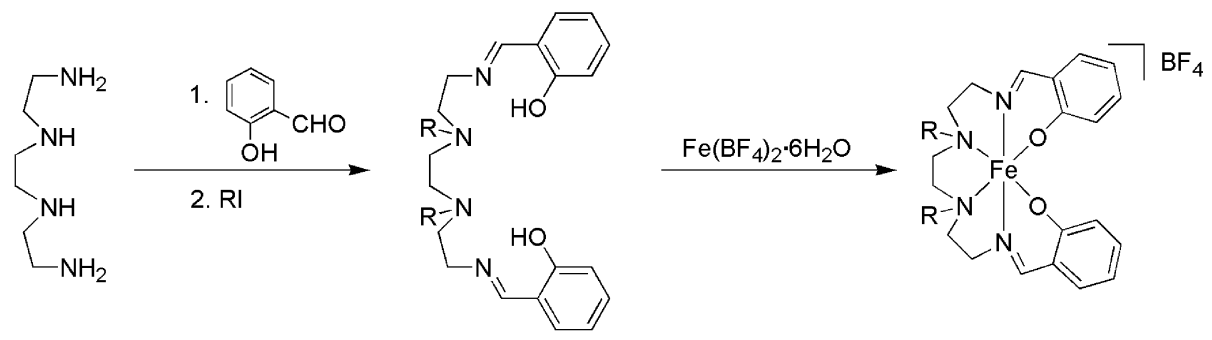

$$
\begin{array}{ll}
\mathrm{H}_{2} \mathrm{~L}_{\mathrm{H}} & (\mathrm{R}=\mathrm{H}) \\
\mathrm{H}_{2} \mathrm{~L}_{\mathrm{C} 6} & \left(\mathrm{R}=\mathrm{C}_{6} \mathrm{H}_{13}\right) \\
\mathrm{H}_{2} \mathrm{~L}_{\mathrm{C} 12} & \left(\mathrm{R}=\mathrm{C}_{12} \mathrm{H}_{25}\right)
\end{array}
$$

$$
\begin{aligned}
& \mathbf{1}\left[\mathrm{FeL}_{\mathrm{C} 0}\right] \mathrm{BF}_{4} \\
& \mathbf{2}\left[\mathrm{FeL}_{\mathrm{C} 6}\right] \mathrm{BF}_{4} \\
& \mathbf{3}\left[\mathrm{FeL}_{\mathrm{C} 12}\right] \mathrm{BF} F_{4}
\end{aligned}
$$

Scheme 1. General method for synthesis of complexes 1-3.

[a] School of Chemistry \& Chemical Biology and the SFI-Strategic Research Cluster in Solar Energy Conversion, University College Dublin Belfield, Dublin 4, Dublin, Ireland Fax: +353-1-716-1178

E-mail: grace.morgan@ucd.ie

[b] Department of Chemistry, The Open University Walton Hall, Milton Keynes, MK7 6AA, United Kingdom

[c] Department of Chemistry, University of Fribourg Ch. du Musée 9, 1700 Fribourg, Switzerland in dihedral angle between the phenoxy rings during spin conversion was considered.

We have recently examined the solution and solid-state thermal response of the $\mathrm{PF}_{6}$ salt of $\left[\mathrm{Fe}(\mathrm{sal})_{2} \text { trien }\right]^{+}$and three derivatives obtained by substituting $\mathrm{C}_{6}, \mathrm{C}_{8}$ or $\mathrm{C}_{18}$ alkyl chains of the phenolate rings. ${ }^{[13]}$ Although alkylation of the phenolate rings was observed to quench SCO in the solid state, there was a marked enhancement in the sharpness of the transition in solution compared to the nonalkylated complex. Analysis of the crystalline packing in 
the $\mathrm{C}_{8}$ amphiphile revealed a cis orientation for the lipophilic groups and a layering of the potentially spin-labile cations. ${ }^{[13]}$ We have therefore expanded our studies to change the morphology of the amphiphile in the solid state by moving the position of the alkylation to the secondary amino groups (Scheme 1). We now report the advantageous effect of this repositioning of the aliphatic chains on the magnetic switching properties.

\section{Results and Discussion}

Functionalised $\left[\mathrm{Fe}(\mathrm{sal})_{2} \text { trien }\right]^{+}$complexes were obtained from condensation of trien with salicylaldehyde, followed by alkylation and subsequent metallation with iron(II) tetrafluoroborate to yield the iron(III) complex as a purple crystalline solid on standing in air (Scheme 1). Plots of magnetic moment vs. temperature for solid samples of the unappended complex $\mathbf{1}$ and functionalised complexes $\mathbf{2}$ and 3 (Figure 1) show that, although the unappended complex 1 is high-spin (HS) down to $10 \mathrm{~K}$, both the $\mathrm{C}_{6^{-}}$and $\mathrm{C}_{12^{-}}$ alkylated complexes show $\mathrm{SCO}$ over this range but with markedly different profiles (see Supporting Information for full magnetic data).

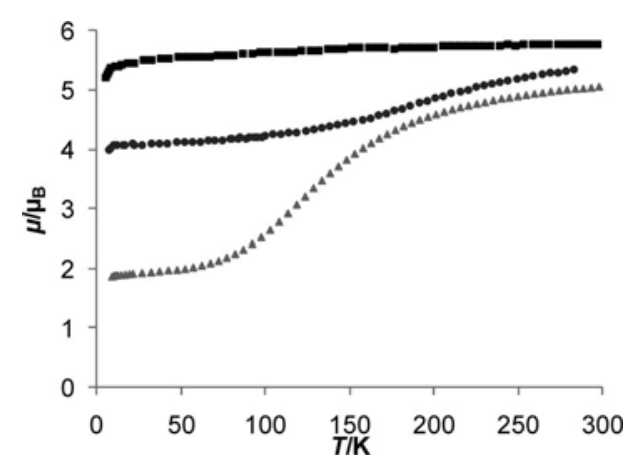

Figure 1. Variable-temperature magnetic moment of $\left[\mathrm{FeL}_{\mathrm{C} 0}\right] \mathrm{BF}_{4}$ (squares), $\left[\mathrm{FeL}_{\mathrm{C} 6}\right] \mathrm{BF}_{4}$ (circles), and $\left[\mathrm{FeL}_{\mathrm{Cl} 2}\right] \mathrm{BF}_{4}$ (triangles).

With the $\mathrm{C}_{12}$-appended ligand the crossover to HS approaches completion, switching from $1.9 \mu_{\mathrm{B}}$ at $10 \mathrm{~K}$ to $5.0 \mu_{\mathrm{B}}$ at room temp. with a gentle sigmoidal profile over $85 \mathrm{~K}$ and $T_{1 / 2}=125 \mathrm{~K}$. This is corroborated by the X-band EPR spectra with typical low-spin (LS) axial $\mathrm{Fe}^{\mathrm{III}}$ signals of $g=2.1$ and $g=2.0$ at $113 \mathrm{~K}$, which diminish on warming to room temperature with concomitant growth of a highspin $g=5.2$ feature typical for anisotropic $S=5 / 2 \mathrm{Fe}^{\mathrm{III}}$ (Figure 2a).

With the shorter $\mathrm{C}_{6}$ amphiphile the crossover is incomplete at both ends of the measured range (Figure 1), with the high-spin fraction falling from $82 \%$ at room temp. to $41 \%$ at $15 \mathrm{~K}$ (assuming $\mu=2.00 \mu_{\mathrm{B}}$ for $\mathrm{LS} \mathrm{Fe} \mathrm{Fe}^{\mathrm{III}}$ with a small orbital contribution and spin-only $\mu=5.92 \mu_{\mathrm{B}}$ for HS $\left.\mathrm{Fe}^{\mathrm{III}}\right)$. This temperature dependence of the HS/LS ratio is also reflected in the EPR spectra (Figure 2b), with characteristic signals of both spin states at room temp. and at $113 \mathrm{~K}$. a)

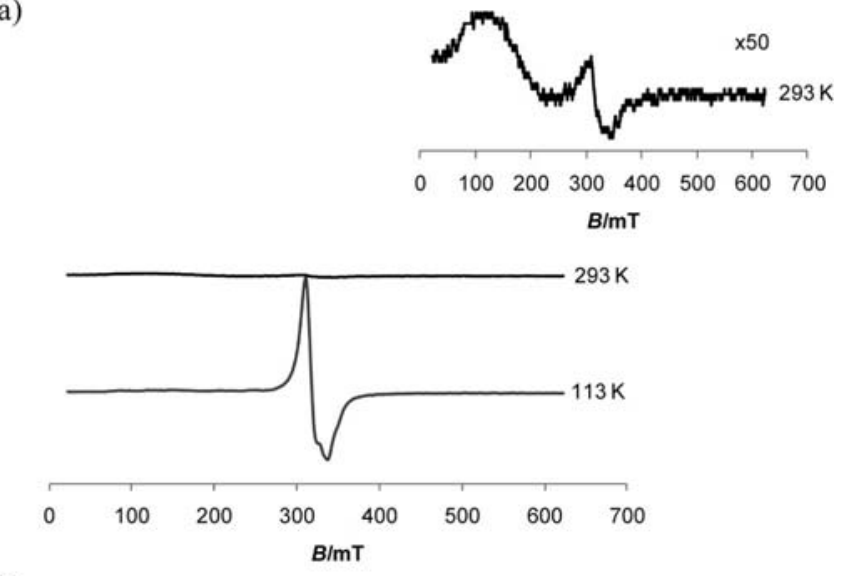

b)
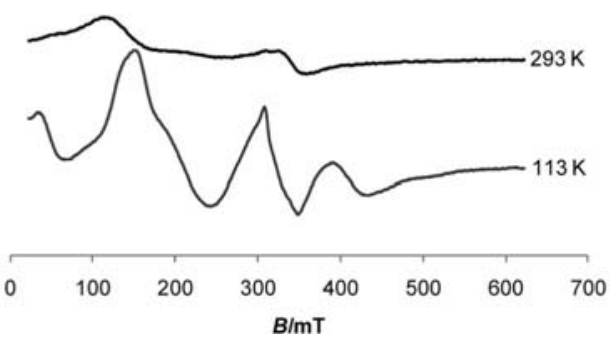

Figure 2. Variable-temperature EPR spectra of (a) $\left[\mathrm{FeL}_{\mathrm{C1} 12}\right] \mathrm{BF}_{4}(\mathbf{3})$ and (b) $\left[\mathrm{FeL}_{\mathrm{C} 6}\right] \mathrm{BF}_{4}$ (2).

Crystals of $\mathbf{1}$ and $\mathbf{2}$ were grown by slow concentration of solutions of each, and single-crystal diffraction data were collected on both at temperatures between 100 and $293 \mathrm{~K}$ (Table 1). The structure of complex 1 at $293 \mathrm{~K}$ (Figure 3) contains one cation and one disordered anion with bond lengths typical for HS Fe ${ }^{\mathrm{III}}$. The local geometry around the coordinated HS ion is highly distorted at $293 \mathrm{~K}$ with elongated bond lengths as expected for the ${ }^{6} \mathrm{~A}$ state where both antibonding orbitals are occupied. The degree of distortion in $\mathrm{Fe}^{\mathrm{II}}$ and $\mathrm{Fe}^{\mathrm{III}}$ is known to be highly sensitive to the spin state, ${ }^{[14]}$ and for 1 the degree of both angular $(\Sigma)^{[15]}$ and trigonal $(\Theta)^{[15]}$ distortion is high as expected (Table 2).

Table 1. Representative bond lengths $[\AA]$ of $\left[\mathrm{FeL}_{\mathrm{H}}\right] \mathrm{BF}_{4}(\mathbf{1})$ at $293 \mathrm{~K}$ and of $\left[\mathrm{FeL}_{\mathrm{C} 6}\right] \mathrm{BF}_{4}(2)$ at 250 and $100 \mathrm{~K}$.

\begin{tabular}{llll}
\hline $\mathrm{Fe}-$ donor & $\mathbf{1}(293 \mathrm{~K})$ & $\mathbf{2}(250 \mathrm{~K})$ & $\mathbf{2}(100 \mathrm{~K})$ \\
\hline $\mathrm{Fe}(1)-\mathrm{O}(2)$ & $1.914(2)$ & $1.902(4)$ & $1.911(2)$ \\
$\mathrm{Fe}(1)-\mathrm{O}(1)$ & $1.916(2)$ & $1.910(3)$ & $1.919(2)$ \\
$\mathrm{Fe}(1)-\mathrm{N}(1)$ & $2.114(2)$ & $2.096(4)$ & $2.093(2)$ \\
$\mathrm{Fe}(1)-\mathrm{N}(4)$ & $2.114(2)$ & $2.107(4)$ & $2.103(3)$ \\
$\mathrm{Fe}(1)-\mathrm{N}(2)$ & $2.157(2)$ & $2.229(4)$ & $2.215(2)$ \\
$\mathrm{Fe}(1)-\mathrm{N}(3)$ & $2.185(2)$ & $2.233(4)$ & $2.227(2)$ \\
$\mathrm{Fe}(2)-\mathrm{O}(4)$ & - & $1.910(3)$ & $1.884(2)$ \\
$\mathrm{Fe}(2)-\mathrm{O}(3)$ & - & $1.896(3)$ & $1.884(2)$ \\
$\mathrm{Fe}(2)-\mathrm{N}(5)$ & - & $2.053(4)$ & $1.944(2)$ \\
$\mathrm{Fe}(2)-\mathrm{N}(8)$ & - & $2.070(4)$ & $1.948(2)$ \\
$\mathrm{Fe}(2)-\mathrm{N}(7)$ & - & $2.165(4)$ & $2.047(2)$ \\
$\mathrm{Fe}(2)-\mathrm{N}(6)$ & - & $2.176(4)$ & $2.058(2)$ \\
\end{tabular}

Single-crystal data for complex 2, collected at 100 and $250 \mathrm{~K}$, reveal two independent cations in the unit cell at both temperatures (Figure 4) with a unique response to cooling for each, which explains the partial crossover. The 


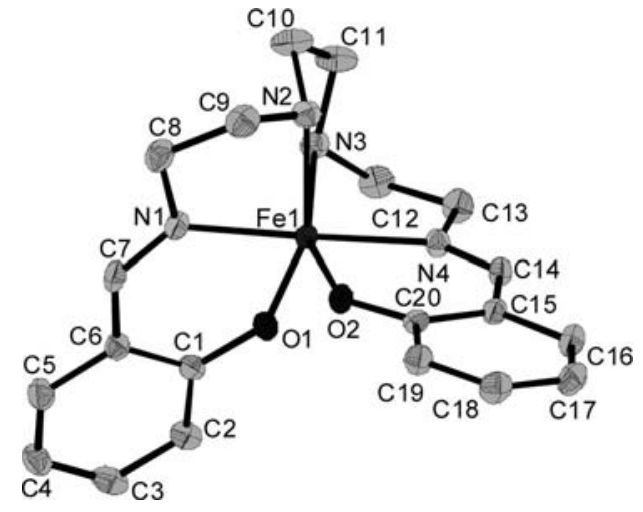

Figure 3. View of the X-ray crystal structure of $\left[\mathrm{FeL}_{\mathrm{H}}\right] \mathrm{BF}_{4}(\mathbf{1})$ at $293 \mathrm{~K}$. Thermal ellipsoids are drawn on the $15 \%$ probability level. The counterion was omitted for clarity.

Table 2. $\Sigma, \Theta$ and $\alpha$ of $\left[\mathrm{FeL}_{\mathrm{H}}\right] \mathrm{BF}_{4}$ at room temp. and $\left[\mathrm{FeL}_{\mathrm{C} 6}\right] \mathrm{BF}_{4}$ at 100 and $250 \mathrm{~K}$.

\begin{tabular}{|c|c|c|c|c|c|c|}
\hline & & & $\Sigma /^{\circ}$ & $\Theta /^{\circ}$ & $\alpha /{ }^{\circ}$ & Spin behavior \\
\hline 1 & {$\left[\mathrm{FeL}_{\mathrm{H}}\right] \mathrm{BF}_{4}$ at $293 \mathrm{~K}$} & & 95.67 & 156.55 & $76.0(1)$ & HS \\
\hline \multirow[t]{2}{*}{2} & {$\left[\mathrm{FeL}_{\mathrm{C} 6}\right] \mathrm{BF}_{4}$ at $250 \mathrm{~K}$} & $\mathrm{Fe} 1$ & 81.78 & 126.50 & $85.1(2)$ & HS \\
\hline & {$\left[\mathrm{FeL}_{\mathrm{C} 6}\right] \mathrm{BF}_{4}$ at $100 \mathrm{~K}$} & & 79.18 & 124.41 & $82.4(1)$ & HS \\
\hline \multirow[t]{2}{*}{2} & {$\left[\mathrm{FeL}_{\mathrm{C} 6}\right] \mathrm{BF}_{4}$ at $250 \mathrm{~K}$} & $\mathrm{Fe} 2$ & 67.22 & 113.34 & $86.3(2)$ & $\mathrm{SCO}$ \\
\hline & {$\left[\mathrm{FeL}_{\mathrm{C} 6}\right] \mathrm{BF}_{4}$ at $100 \mathrm{~K}$} & & 65.02 & 103.33 & $86.3(1)$ & $\mathrm{SCO}$ \\
\hline
\end{tabular}

$\mathrm{Fe}(1)$ site clearly remains HS down to $100 \mathrm{~K}$ with no significant change in bond lengths, whereas the depopulation of antibonding orbitals, which accompanies spin crossover in $\mathrm{Fe}(2)$, is unambiguously reflected in shorter bonds on cooling (Table 1). This is in line with the magnetic and EPR data, which show a partial crossover with approximately half the molecules undergoing thermally induced spin transition between 50 and $150 \mathrm{~K}$. The difference in thermal spin response between the two crystallographically independent iron centers in $\mathbf{2}$ is also reflected by the significantly more pronounced distortion in $\mathrm{HS}$ ion $\mathrm{Fe} 1$ compared to $\mathrm{Fe} 2$ (cf. $\Sigma$ and $\Theta$; Table 2).

The focus of our structural investigation was a comparison of the packing between $\mathbf{1}$ and $\mathbf{2}$ in the search for a coherent connection between intermolecular interactions and magnetic response (see Supporting Information for packing diagrams). This is particularly pertinent for our system where other packing effects such as ligand sphere, phenolate substitution, counterion and lattice solvent are kept constant. Possible intermolecular interactions including van der Waals distances, hydrogen bonding, $\pi-\pi$ and anion $-\pi$ interactions were all investigated, but no correlation between packing and thermal spin response emerged (see Supporting Information for comparison of close contacts in $\mathrm{HS}$ and $\mathrm{SCO}$ sites in 2).

The dihedral angle $a$ between the two phenoxy rings was also analysed but, unlike earlier reports, ${ }^{[12]}$ we did not observe any correlation between changes in this parameter
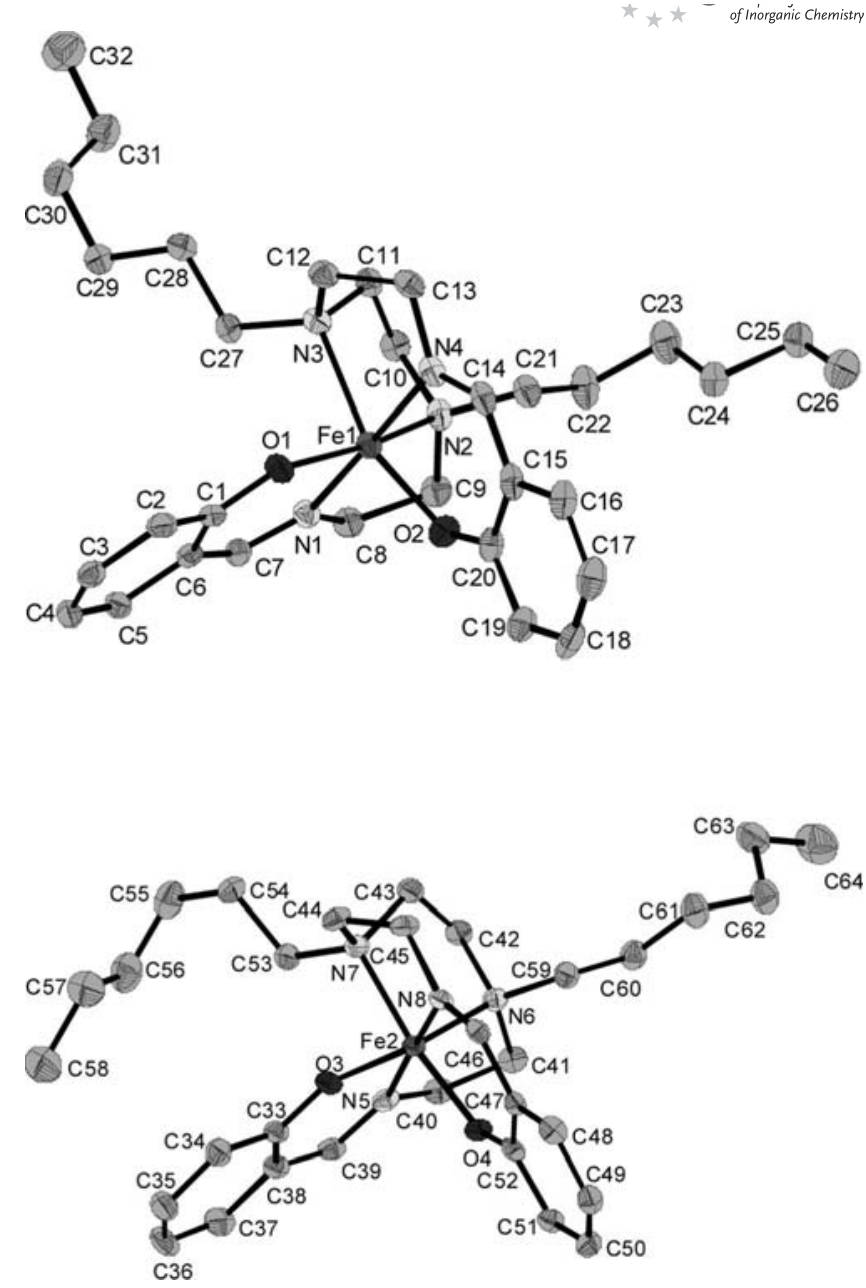

Figure 4. View of the X-ray crystal structure of $\left[\mathrm{FeL}_{\mathrm{C} 6}\right] \mathrm{BF}_{4}(2)$ at $100 \mathrm{~K}$. Thermal ellipsoids are drawn on the $50 \%$ probability level. The counterion was omitted for clarity.

and SCO behaviour, $a$ being very similar for both HS Fel and $\mathrm{SCO} F \mathrm{Fe}$ in complex 2 and remaining unchanged upon SCO (Table 2).

The magnetic behaviour of (saltrien)Fe $\mathrm{Fe}^{\mathrm{III}}$ derivatives is therefore unpredictable. An apparent lack of correlation with any single geometric parameter indicates more complex influences, which are not evident from the available data.

\section{Conclusions}

We have shown that appropriate functionalisation of the HS tetrafluoroborate salt of $\left[\mathrm{Fe}(\mathrm{sal})_{2} \text { trien }\right]^{+}$switches on $\mathrm{SCO}$ in this ion. Alkylation with short $\mathrm{C}_{6}$ chains induces a partial $\mathrm{SCO}$, and increasing the chain length to $\mathrm{C}_{12}$ brings the SCO to completion over $10-293 \mathrm{~K}$. Work is now underway to investigate the effects of longer-chain substitution on thermal magnetic response in this ion in both the solid state and solution and soft matter environments. 


\section{Experimental Section}

Preparation of Ligands: $\mathrm{H}_{2} \mathrm{~L}_{\mathrm{C} 6}$, and $\mathrm{H}_{2} \mathrm{~L}_{\mathrm{C} 12}$ were prepared by using inert and dry conditions. Dry acetonitrile was used for the synthesis of the ligands. The complexation was carried out under aerobic conditions.

Complex 1: To a solution of triethylenetetramine (0.292 g, $2 \mathrm{mmol})$ in methanol $(25 \mathrm{~mL})$, salicylaldehyde $(0.488 \mathrm{~g}, 4 \mathrm{mmol})$ was added. After $15 \mathrm{~min}$, solid $\mathrm{Fe}\left(\mathrm{BF}_{4}\right)_{2} \cdot 6 \mathrm{H}_{2} \mathrm{O}(0.676 \mathrm{~g}, 2 \mathrm{mmol})$ was added to give a deep purple solution that was stirred at room temp. for $30 \mathrm{~min}$. The solvent was evaporated at room temp., and after $3 \mathrm{~d}$ black crystals were obtained. Yield: $430 \mathrm{mg}(43 \%)$. IR (KBr): $\tilde{v}=$ 3858 (vw), 3743 (w), 3472 (m), 3408 (m), 3281 (m), 3122 (w), 2932 (w), $2361(\mathrm{~m}), 1623$ (s), 1540 (s), 1450 (s), 1302 (s), 1203 (m), 1079 (s), $895(\mathrm{~m}), 773$ (s), 606 (m), $521(\mathrm{~m}), 467$ (w), $393(\mathrm{~m}), 327(\mathrm{w})$, 223 (s) $\mathrm{cm}^{-1}$. HRMS (ESI): calcd. for $\mathrm{C}_{20} \mathrm{H}_{24} \mathrm{FeN}_{4} \mathrm{O}_{2}[\mathrm{M}-$ $\left.\mathrm{BF}_{4}\right]^{+}$409.1327, found 409.1313. $\mathrm{C}_{20} \mathrm{H}_{24} \mathrm{BF}_{4} \mathrm{FeN}_{4} \mathrm{O}_{2}$ (495.03): calcd. C 48.48, H 4.89, N 11.31; found C 48.23, H 4.82, N 11.14.

Complex 2: To a solution of triethylenetetramine (0.292 g, $2 \mathrm{mmol}$ ) in dry acetonitrile $(50 \mathrm{~mL})$, salicylaldehyde $(0.488 \mathrm{~g}, 4 \mathrm{mmol})$ was added. After $15 \mathrm{~min}$, molecular sieves and anhydrous $\mathrm{K}_{2} \mathrm{CO}_{3}$ $(0.552 \mathrm{~g}, 4 \mathrm{mmol})$ were added. The reaction mixture was stirred for $10 \mathrm{~min}$, after which 1-bromohexane $(0.660 \mathrm{~g}, 4 \mathrm{mmol})$ and $\mathrm{KI}$ ( $0.664 \mathrm{~g}, 4 \mathrm{mmol})$ were added, and the suspension was refluxed for $48 \mathrm{~h}$. The reaction mixture was filtered and the solvent removed under reduced pressure. The resulting oil was dissolved in chloroform and washed with brine, and the organic fraction was dried with anhydrous $\mathrm{MgSO}_{4}$ to obtain $\mathrm{H}_{2} \mathrm{~L}_{\mathrm{C} 6}$ as a bright yellow oil. The ligand $(0.551 \mathrm{~g}, 1 \mathrm{mmol})$ was dissolved in methanol $(20 \mathrm{~mL})$, and solid $\mathrm{Fe}\left(\mathrm{BF}_{4}\right)_{2} \cdot 6 \mathrm{H}_{2} \mathrm{O}(0.338 \mathrm{~g}, 1 \mathrm{mmol})$ was added togive a deep purple solution that was stirred at room temp. for $30 \mathrm{~min}$. The solvent was evaporated, and the resulting purple oil was dissolved in chloroform $(10 \mathrm{~mL})$ and filtered through a bed of $\mathrm{SiO}_{2}$ by using chloroform to elute the product. The solvent was removed under reduced pressure, and the residue was dissolved in tetrahydrofuran $(10 \mathrm{~mL})$ and purified on a column of $\mathrm{Al}_{2} \mathrm{O}_{3}$ by using as eluent first tetrahydrofuran and then ethanol. The ethanol was removed under reduced pressure to yield a purple oil that was recrystallised from methanol. The solvent was evaporated slowly at room temp., and after $2 \mathrm{~d}$ black crystals were obtained. Yield: $100 \mathrm{mg}(15 \%)$. IR $(\mathrm{KBr}): \tilde{\mathrm{v}}=3858(\mathrm{vw}), 3744(\mathrm{w}), 3619(\mathrm{w}), 3442(\mathrm{vw}), 3059(\mathrm{w})$, 2926 (m), 2861 (m), 2361 (m), 1620 (s), 1540 (s), 1464 (s), 1302 (s), 1199 (m), 1053 (s), 897 (m), 759 (s), 602 (m), 517 (w), 397 (m), 324 (w), 224 (s) $\mathrm{cm}^{-1}$. HRMS (ESI): calcd. for $\mathrm{C}_{32} \mathrm{H}_{48} \mathrm{FeN}_{4} \mathrm{O}_{2}[\mathrm{M}-$ $\left.\mathrm{BF}_{4}\right]^{+}$576.3127, found 576.3130. $\mathrm{C}_{32} \mathrm{H}_{48} \mathrm{BF}_{4} \mathrm{FeN}_{4} \mathrm{O}_{2}$ (663.22): calcd. C 57.90, H 7.28, N 8.45; found C 57.01, H 7.32, N 7.81.

Complex 3: The method of preparation of $\mathbf{3}$ was similar to that for 2, but 1-bromododecane $(0.997 \mathrm{~g}, 4 \mathrm{mmol})$ was used instead of 1bromohexane. After purification and recrystallisation, a purple wax was obtained. The wax was dissolved in chloroform and layered with $n$-hexane. After $5 \mathrm{~d}$, small black crystals were obtained. Yield: $125 \mathrm{mg}$ (15\%). IR (KBr): $\tilde{v}=3858(\mathrm{vw}), 3744(\mathrm{w}), 3649$ (vw), 3059 (vw), 2922 (m), 2851 (m), 2361 (m), 1624 (m), 1542 (m), 1465 (m), 1307 (m), 1198 (w), 1059 (m), 898 (w), 755 (m), 607 (w), $516(\mathrm{vw})$, 401 (w), 328 (vw), 222 (s) $\mathrm{cm}^{-1}$. HRMS (ESI): calcd. for $\mathrm{C}_{44} \mathrm{H}_{72} \mathrm{FeN}_{4} \mathrm{O}_{2}\left[\mathrm{M}-\mathrm{BF}_{4}\right]^{+}$744.5005, found 744.5026. $\mathrm{C}_{44} \mathrm{H}_{72} \mathrm{BF}_{4} \mathrm{FeN}_{4} \mathrm{O}_{2}$ (831.40): calcd. C 63.51, $\mathrm{H} 8.73, \mathrm{~N}$ 6.74; found C 63.69, H 9.01, N 5.94.

X-ray Crystal Structure Determination: Crystal data at all temperatures were collected by using a Bruker SMART APEX CCD area detector diffractometer. A full sphere of reciprocal space was scanned by $\phi-\omega$ scans. Pseudo-empirical absorption correction based on redundant reflections was performed by the program SADABS. ${ }^{[16]}$ The structures were solved by direct methods by using SHELXS-97 ${ }^{[17]}$ and refined by full-matrix least squares on $F^{2}$ for all data by using SHELXL-97. ${ }^{[17]}$ Hydrogen atoms were added at calculated positions and refined by using a riding model. Their isotropic temperature factors were fixed to 1.2 times (1.5 times for methyl groups) the equivalent isotropic displacement parameters of the parent carbon atom. Anisotropic thermal displacement parameters were used for all non-hydrogen atoms. Data for 1 (293 K): $\mathrm{C}_{20} \mathrm{H}_{24} \mathrm{BF}_{4} \mathrm{FeN}_{4} \mathrm{O}_{2}\left(\mathrm{Mr}=495.09, \rho=1.484 \mathrm{~g} \mathrm{~cm}^{-3}\right), \lambda=0.71073 \AA$, crystal system: monoclinic, space group: $P 2_{1} / c$ (\#14), $a=$ 9.178(1) $\AA, b=25.282(3) \AA, c=9.654(1) \AA, \beta=98.374(2)^{\circ}, V=$ 2216.3(4) $\AA^{3}, Z=4$. Data for $2(250 \mathrm{~K}): \mathrm{C}_{32} \mathrm{H}_{48} \mathrm{BF}_{4} \mathrm{FeN}_{4} \mathrm{O}_{2}(M r=$ 663.40, $\left.\rho=1.325 \mathrm{~g} \mathrm{~cm}^{-3}\right), \lambda=0.71073 \AA$, crystal system: orthorhombic, space group: $P c a 2_{1}$ (\#29), $a=31.1434(19) \AA, b=$ 19.2970(11) $\AA, c=11.1027(7) \AA, V=6672.4(7) \AA^{3}, Z=8$. Data for $2(100 \mathrm{~K}): \mathrm{C}_{32} \mathrm{H}_{48} \mathrm{BF}_{4} \mathrm{FeN}_{4} \mathrm{O}_{2}\left(M r=663.40, \rho=1.363 \mathrm{~g} \mathrm{~cm}^{-3}\right)$, $\lambda=0.71073 \AA$, crystal system: orthorhombic, space group: $P c a 2_{1}$ (\#29), $a=30.654(3) \AA, b=19.1482(18) \AA, c=11.0156(10) \AA, V=$ 6465.8(10) $\AA^{3}$ and $Z=8$. CCDC-746613 (1), -746611 (2, $\left.100 \mathrm{~K}\right)$ and $-746612(2,250 \mathrm{~K})$ contain the supplementary crystallographic data for this paper. These data can be obtained free of charge from The Cambridge Crystallographic Data Centre via www.ccdc.cam. ac.uk/data_request/cif.

Supporting Information (see footnote on the first page of this article): Tables and graphs of magnetic data for complexes $\mathbf{1}-\mathbf{3}$, tables of short contacts for complex $\mathbf{2}$ and packing diagrams for complexes $\mathbf{1}$ and $\mathbf{2}$.

\section{Acknowledgments}

Funding of this work by the Irish Research Council for Science, Engineering and Technology and the Swiss National Science Foundation under the ERA-Chemistry programme is gratefully acknowledged. The award of a travel grant by University College Dublin to complete the magnetic measurements and an equipment grant to fund the EPR is also gratefully acknowledged. M. A. is very grateful for an Alfred Werner assistant professorship.

[1] a) O. Kahn, J.-P. Launay, Chemtronics 1988, 3, 140-144; b) O. Kahn, J. Kröber, C. Jay, Adv. Mater. 1992, 4, 718-728.

[2] a) O. Kahn, C. J. Martinez, Science 1998, 279, 44 48; b) H. Soyer, E. Dupart, C. J. Gomez-Garcia, C. Mingotaud, P. Delhaes, Adv. Mater. 1999, 11, 382-384; c) P. J. Van Koningsbruggen, Top. Curr. Chem. 2004, 233, 123-149; d) Y. Garcia, V. Niel, M. C. Muñoz, J. A. Real, Top. Curr. Chem. 2004, 233, 229-257; e) M. Seredyuk, A. Gaspar, M. Muñoz, M. Verdaguer, F. Villain, P. Gütlich, Eur. J. Inorg. Chem. 2007, 4481-4491.

[3] a) A. Ruaudel-Teixier, A. Barraud, P. Coronel, O. Kahn, Thin Solid Films 1988, 160, 107-115; b) O. Roubeau, B. Agricole, R. Clerac, S. Ravaine, J. Phys. Chem. B 2004, 108, 15110-15116; c) S. Cobo, G. Molnar, J. A. Real, A. Bousseksou, Angew. Chem. Int. Ed. 2006, 45, 5786-5789; d) E. Coronado, J. GalanMascaros, M. Monrabal-Capilla, J. Garcia-Martinez, P. PardoIbanez, Adv. Mater. 2007, 19, 1359-1361; e) M. Seredyuk, A. B. Gaspar, V. Ksenofontov, Y. Galyametdinov, J. Kusz, P. Gütlich, J. Am. Chem. Soc. 2008, 130, 1431-1439; f) I. Boldog, A. B. Gaspar, V. Martínez, P. Pardo-Ibañez, V. Ksenofontov, A. Bhattacharjee, P. Gütlich, J. A. Real, Angew. Chem. Int. Ed. 2008, 47, 6433-6437; g) F. Volatron, L. Catala, E. Rivière, A. Gloter, O. Stéphan, T. Mallah, Inorg. Chem. 2008, 47, 6584 6586.

[4] H. Toftlund, J. J. McGarvey, Top. Curr. Chem. 2004, 233, 151166. 
[5] P. J. van Koningsbruggen, Y. Maeda, H. Oshio, Top. Curr. Chem. 2004, 233, 259-324.

[6] a) K. M. Kadish, K. Das, D. Schaeper, C. L. Merrill, B. R. Welch, L. J. Wilson, Inorg. Chem. 1980, 19, 2816-2821; b) K. M. Kadish, C. H. Su, L. J. Wilson, Inorg. Chem. 1982, 21 , 2312-2314; c) T. Zhu, C. H. Su, D. Schaeper, B. K. Lemke, L. J. Wilson, K. M. Kadish, Inorg. Chem. 1984, 23, 4345-4349.

[7] M. F. Tweedle, L. J. Wilson, J. Am. Chem. Soc. 1976, 98, 4824 4834.

[8] a) E. V. Dose, M. A. Hoselton, N. Sutin, M. F. Tweedle, L. J. Wilson, J. Am. Chem. Soc. 1978, 100, 1141-1147; b) R. A. Binstead, J. K. Beattie, E. V. Dose, M. F. Tweedle, L. J. Wilson, J. Am. Chem. Soc. 1978, 100, 5609-5614; c) R. A. Binstead, J. K. Beattie, T. G. Dewey, D. H. Turner, J. Am. Chem. Soc. 1980, 102, 6442-6451; d) H. D. Burrows, S. J. Formosinho, J. Chem. Soc. Faraday Trans. 2 1986, 82, 1563-1568; e) S. Schenker, A. Hauser, R. M. Dyson, Inorg. Chem. 1996, 35, 4676-4682.
[9] E. Sinn, G. Sim, E. V. Dose, M. F. Tweedle, L. J. Wilson, J. Am. Chem. Soc. 1978, 100, 3375-3390.

[10] Y. Nishida, K. Kino, S. Kida, J. Chem. Soc., Dalton Trans. 1987, 1957-1961.

[11] S. Dorbes, L. Valade, J. A. Real, C. Faulmann, Chem. Commun. 2005, 69-71.

[12] R. Pritchard, S. A. Barrett, C. A. Kilner, M. A. Halcrow, Dalton Trans. 2008, 3159-3168.

[13] C. Gandolfi, C. Moitzi, P. Schurtenberger, G. G. Morgan, M. Albrecht, J. Am. Chem. Soc. 2008, 130, 14434-14435.

[14] P. Guionneau, M. Marchivie, G. Bravic, J.-F. Létard, D. Chasseau, Top. Curr. Chem. 2004, 234, 97-128.

[15] M. G. B. Drew, C. J. Harding, V. McKee, G. G. Morgan, J. Nelson, J. Chem. Soc., Chem. Commun. 1995, 1035-1038.

[16] SADABS, Bruker AXS Inc., Madison, Wisconsin, USA, 2001. [17] G. M. Sheldrick, Acta Crystallogr., Sect. A 2008, 64, 112-122. 